Waste and Biomass Valorization

\title{
A mini review of the techno-environmental sustainability of biological processes for the treatment of high organic content industrial wastewater streams \\ --Manuscript Draft--
}

Manuscript Number:

Full Title:

Article Type:

Keywords:

Corresponding Author:
WAVE-D-16-00729R1

A mini review of the techno-environmental sustainability of biological processes for the treatment of high organic content industrial wastewater streams

\section{S.I. : Waste Management \& Valorization}

Industrial Wastewater, Advanced Anaerobic Technologies, Biogas Production, Life

Cycle Assessment, Circular Economy

Evina Katsou

Brunel University

UNITED KINGDOM

\section{Corresponding Author Secondary}

Information:

Corresponding Author's Institution:

Brunel University

\section{Corresponding Author's Secondary} Institution:

\section{First Author:}

Theoni - Massara

First Author Secondary Information:

Order of Authors:

Theoni - Massara

Okan Tarik Komesli

Onur Sozudogru

Senba Komesli

Evina Katsou

\section{Order of Authors Secondary Information:}

Funding Information:

Royal Society - Newton Advanced

Fellowship

Dr Evina Katsou
Abstract:

Response to Reviewers:

\section{(2015/R2)}

Industrial wastewater contains complex and slowly biodegradable compounds often ineffectively treated by conventional activated sludge (CAS) systems. Alternatively, advanced anaerobic technologies are implemented. The current study reviews different potential anaerobic schemes, factors influencing their final performance and optimum combinations of operational/design parameters. Anaerobic membrane bioreactors, upflow anaerobic sludge blanket reactors, expanded granular sludge beds, anaerobic hybrid reactors and inverse fluidized bed reactors are discussed. Their major advantages include: low energy requirements, energy recovery through biogas generation and high organic load removal. $\mathrm{pH} \sim 7$, operation in a mesophilic environment and a hydraulic retention time long enough to enable anaerobic digestion in economically accepted reactor volumes are conditions that optimize the performance of anaerobic configurations. The evaluation additionally considers environmental aspects. The life cycle assessment of anaerobic industrial wastewater treatment reveals its positive environmental effect in terms of greenhouse gases emissions. Methane (a greenhouse gas) primarily contained in the biogas, despite being produced during anaerobic digestion, is utilized for energy production (heating, electricity) instead of being emitted to the atmosphere. Finally, anaerobic wastewater treatment is analyzed as part of the European Commission Innovation Deal that aims at converting conventional wastewater treatment plants to water resource recovery facilities able to combine sustainable wastewater treatment and water reuse.

Reviewer \#1: The topic and the results of the current study are generally very 
interesting and satisfactorily explained. I recommend the publication after the following minor revisions:

1.'An example for that is the lab-scale study of Jiang et al. [22] who implemented a SBR for the treatment of aniline-rich industry wastewater and observed a COD removal of $95.80 \%$.': Could the authors briefly present $1-2$ more examples?

Following the reviewer's comment, we included the following extra examples in section 2 of the revised manuscript: "Similarly, Rajab et al. [81] achieved an average total COD removal of $97 \pm 2 \%$ in a lab-scale integrated anaerobic/aerobic SBR treating poultry slaughterhouse wastewater. COD removal higher than $95 \%$ was obtained by Xiao et al. [82] for the treatment of wastewater generated from silicon solar cell manufacture containing isopropyl alcohol operating a lab-scale achieve SBR. Anaerobic treatment is another process that has been widely used for industrial influents treatment [5]."

2.'In a suspended-growth configuration, a greater in a suspended-growth configuration, a greater number of microorganisms can be retained compared to the attached-growth systems; therefore, a smaller tank volume is required [25].': Which means that the operational cost is reduced? Please, briefly comment on that.

Following the reviewer's comment, we revised and rewrote this part of section 2 of the revised manuscript as follows: "The main advantages of attached-growth over suspended-growth configurations include lower energy requirements, absence of sludge bulking problems and bigger resistance to system shocks [24-25]."

3.'They optimized the operation by investigating in advance the response of the active UASB microbial community to different OLRs [57].': Please, clarify the 'in advance'. Did they do any preliminary experiments?

Following the reviewer's comment, we clarified this point in section 3.1 of the revised manuscript by adding the following: "Microbial network analysis enabled monitoring the response of the active UASB microbial community to different OLRs and, thus, optimizing the process operation."

4.'Bialek et al. [10] applied psychrophilic conditions in order to investigate the efficiency of the anaerobic treatment in northern countries where the yearly average temperature is below $15^{\circ} \mathrm{C}$.': Please, make a small comment on the efficiency of the process under the specific conditions of the study.

Following the reviewer's comment, we clarified this point in section 3.4 of the revised manuscript by adding the following: "At $10^{\circ} \mathrm{C}$, the system presented a low average removal efficiency $(\sim 69 \%)$ and unstable operation with hydrolysis being the ratelimiting step. Biofilm overgrowth resulted in a decrease in the population of hydrogenotrophic methanogens; the latter limited methane production."

Reviewer \#2: The main goal of the paper "Benchmarking of low environmental footprint biological processes for the treatment of industrial waste streams" is to analyze different potential anaerobic technologies available to date for the treatment of industrial wastewater. To this aim, not only the technical parameters but also the environmental performance of the different configurations are compared each other in order to find the optimal alternative. It is reflected the work that has been performed in the preparation of this manuscript. However, I consider that there are some minor aspects that should be improved before its publication, which are described below: 1.Title. As mentioned, the authors aim to review the potential alternatives for the management of industrial wastewater based on anaerobic technologies. However, the title of the manuscript may lead to confusion, since readers could interpret that primary data from own configurations will be evaluated and compared with related studies available in literature. In this sense, I encourage authors to modify the title of the manuscript to make clear that a review process is reported in this study focusing on the techno-environmental sustainability of different technologies for the treatment of wastewater from industrial framework. A proposal: "A review of the technoenvironmental sustainability of biological processes for the treatment of industrial waste streams".

Following the reviewer's comment, we rephrased the title of the revised manuscript as follows: "A mini review of the techno-environmental sustainability of biological processes for the treatment of high organic content industrial wastewater streams". 2.Keywords. In my opinion, some of the keywords could be improved. For example, since methane is the main component of biogas, which is used for energy production, I would change "methane" by "methane valorization", "biogas generation" or "energy production". In my opinion, these terms make more sense in accordance with the purpose of the paper. On the other hand, the authors propose two keywords that are 
redundant: "advanced anaerobic processes" and "anaerobic digestion". From my perspective, the latter could be removed from the list.

Following the reviewer's comment as well as in an effort to better describe the content of the revised manuscript, we revised the keywords as follows: "Industrial Wastewater, Advanced Anaerobic Technologies, Biogas Production, Life Cycle Assessment, Circular Economy".

3.Introduction. In the last lines of the Introduction section, the authors explain that they will also discuss "the integration of an anaerobic step in systems including a sequence of different processes for industrial wastewater treatment". However, it is a bit difficult to identify in which part of the manuscript this task is carried out. I assume that the authors make reference to the last part of the Environmental Assessment section where they conclude that "the implementation of integrated systems combining multiple steps is a significantly sustainable option for industrial wastewater treatment". However, this issue is not entirely clear. I would suggest to rewrite this part of the Introduction to better clarify that the biological processes previously analyzed will be also evaluated in combination with other treatment technologies which are not necessarily anaerobic or CAS-type.

Following the reviewer's comment as well as in an effort to better describe the content of the revised manuscript, we revised this part of the introduction as follows: "Moreover, life cycle assessment (LCA) of anaerobic industrial wastewater treatment was presented as a method for holistically evaluating the environmental impact resulting from the application of such technologies. Finally, the analysis considered the contribution of anaerobic wastewater treatment technologies to the concept of circular economy by considering the European Commission Innovation Deal that is based on combining sustainable anaerobic membrane wastewater treatment and water reuse." 4.Environmental assessment. In line with the above, if this clarification is described in the Introduction, the last paragraph of the Environmental assessment section focused on other technologies apart from biological alternatives acquire force and sense. By contrast, it seems that the last paragraph based on physicochemical processes are outside the boundaries of the study.

Following the reviewer's comment as well as in an effort to better describe the content of the revised manuscript, we revised this part of section 4 as follows: "The way in which the operating strategy and design affect the environmental performance of anaerobic technology is still relatively unclear [80]. In this section though, it has been indicated that anaerobic reactors can have a positive environmental assessment especially in terms of GHG emissions. In any case, anaerobic wastewater treatment should be designed considering both economic (e.g. construction, operation, maintenance costs, etc.) and environmental aspects (e.g. eutrophication, GHG emissions, marine ecotoxicity, etc.) to achieve a positive environmental performance. Marine and freshwater eutrophication can only be decreased if the anaerobic treatment is coupled with suitable anaerobic/anoxic post-treatment."

5.English. The English style and grammar are adequate. I only would suggest a revision of the manuscript in order to correct some typographic mistakes.

Following the reviewer's comment, we went through the whole manuscript to correct any typos.

6.References. In general, the manuscript is adequately documented. However, any reference from Waste and Biomass Valorization can be found in the text, so that I suggest performing a review on similar articles published in this journal to be included in the references list. Moreover, more attention should be paid on the criteria used in the reference list, since the names of the journals appear indistinctly in either complete or abbreviated format, as well as both upper and lower case. This is the case of references 2 and 12, as an example. Please, review to standardize the format in all cases.

Following the reviewer's comment, we went through the reference list to make sure that the referencing style is homogeneous and in accordance with the journal's guidelines. We also added references from the journal.

Reviewer \#3: Well presented paper offering a review of different anaerobic streams and at the same time considering environmental impacts via LCA.

It's well-structured and provides a good analysis and evaluation of the available options taking into account the main parameters in question. 


\section{Title:}

A mini review of the techno-environmental sustainability of biological processes for the treatment of high organic content industrial wastewater streams

Theoni M. Massara ${ }^{1,2} \cdot$ Okan Tarik Komesli $^{3} \cdot$ Onur Sozudogru $^{3} \cdot$ Senba Komesli $^{3}$ Evina Katsou ${ }^{1,2}$

${ }^{1}$ Department of Mechanical, Aerospace and Civil Engineering, Brunel University London, Uxbridge Campus, Middlesex, UB8 3PH, Uxbridge, UK.

${ }^{2}$ Institute of Environment, Health and Societies, Brunel University London, Uxbridge Campus, Middlesex, UB8 3PH, Uxbridge, UK.

3 Department of Environmental Engineering, Faculty of Engineering, Ataturk University, 25240, Erzurum, Turkey.

\section{Corresponding Author:}

Dr Evina Katsou, Email: evina.katsou@ brunel.ac.uk, Tel: +44 (0)1895 265721

Acknowledgments The authors would like to acknowledge the Royal Society for funding the current research: Ad-Bio: Advanced Biological Wastewater Treatment Processes, Newton Advanced Fellowship - 2015/R2. Theoni M. Massara is grateful to the Natural Environment Research Council (NERC) of the UK for the 4-year full PhD studentship. 
Graphical Abstract

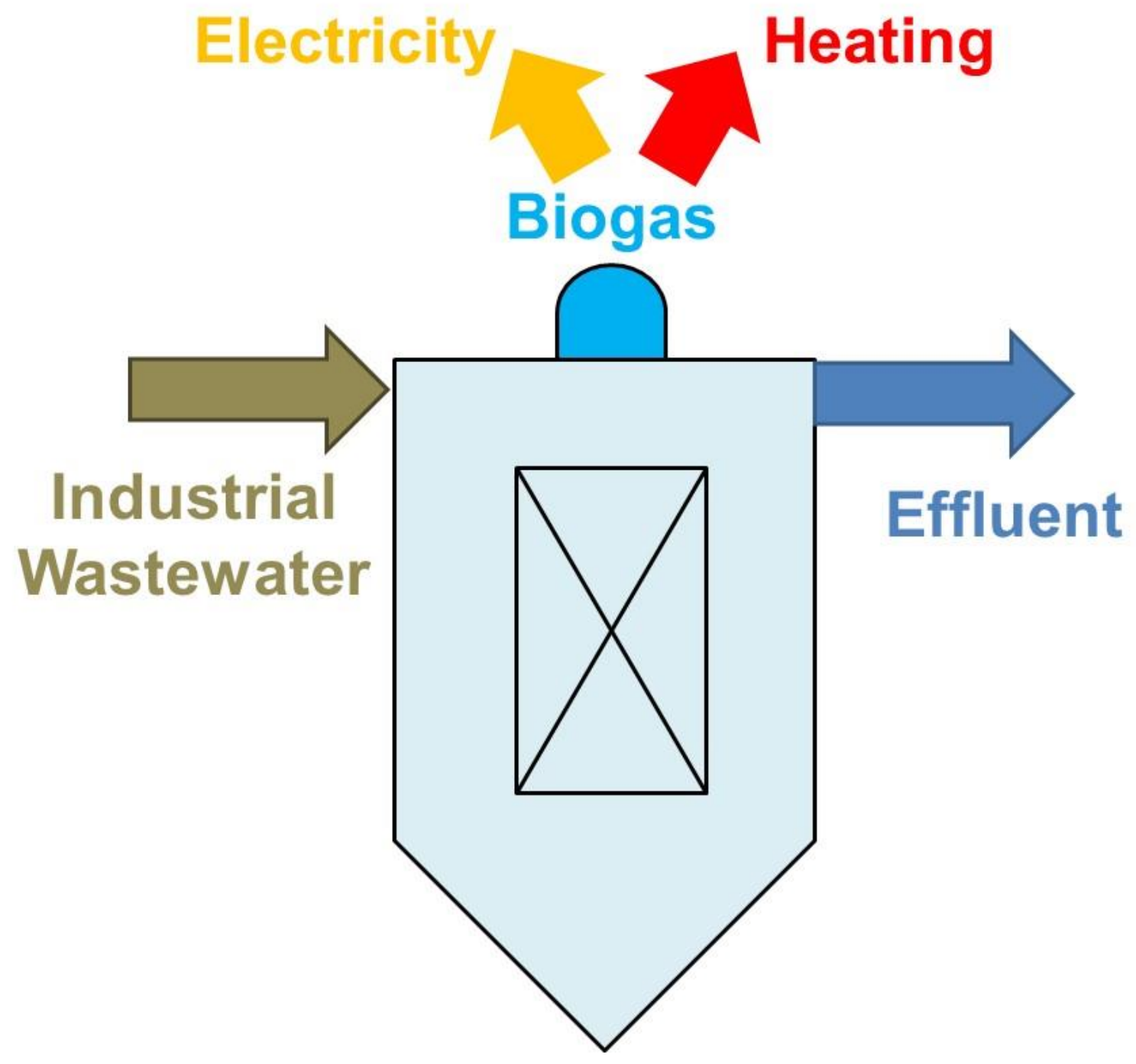


Abstract Industrial wastewater contains complex and slowly biodegradable compounds often ineffectively treated by conventional activated sludge (CAS) systems. Alternatively, advanced anaerobic technologies are implemented. The current study reviews different potential anaerobic schemes, factors influencing their final performance and optimum combinations of operational/design parameters. Anaerobic membrane bioreactors, upflow anaerobic sludge blanket reactors, expanded granular sludge beds, anaerobic hybrid reactors and inverse fluidized bed reactors are discussed. Their major advantages include: low energy requirements, energy recovery through biogas generation and high organic load removal. $\mathrm{pH}$ 7, operation in a mesophilic environment and a hydraulic retention time long enough to enable anaerobic digestion in economically accepted reactor volumes are conditions that optimize the performance of anaerobic configurations. The evaluation additionally considers environmental aspects. The life cycle assessment of anaerobic industrial wastewater treatment reveals its positive environmental effect in terms of greenhouse gases emissions. Methane (a greenhouse gas) primarily contained in the biogas, despite being produced during anaerobic digestion, is utilized for energy production (heating, electricity) instead of being emitted to the atmosphere. Finally, anaerobic wastewater treatment is analyzed as part of the European Commission Innovation Deal that aims at converting conventional wastewater treatment plants to water resource recovery facilities able to combine sustainable wastewater treatment and water reuse.

Keywords Industrial Wastewater, Advanced Anaerobic Technologies, Biogas Production, Life Cycle Assessment, Circular Economy

\section{Nomenclature}

\begin{tabular}{ll}
\hline Nomenclature & \\
\hline ABR & Anaerobic Baffled Reactor \\
AH & Anaerobic Hybrid \\
AnMBR & Anaerobic Membrane Bioreactor \\
AS & Activated Sludge \\
CAS & Conventional Activated Sludge \\
COD & Chemical Oxygen Demand \\
d & Days \\
h & Hours \\
EGSB & Expanded Granular Sludge Bed \\
GHG & Greenhouse gas \\
\hline
\end{tabular}




\begin{tabular}{ll}
\hline HRT & Hydraulic Retention Time \\
IFBR & Inverse Fluidized Bed Reactor \\
LCA & Life Cycle Assessment \\
OLR & Organic Loading Rate \\
SBR & Sequencing Batch Reactor \\
SRT & Sludge Retention Time \\
UASB & Upflow Anaerobic Sludge Blanket Reactor \\
\hline
\end{tabular}

\section{Introduction}

Wastewater originating from industrial activities contains complex and slowly biodegradable organic compounds which are not easy to treat [1]. Thus, appropriate treatment of industrial wastewater is important in order to avoid phenomena, such as eutrophication of surface waters, hypoxia and algal bloom, which cause pollution of the scarce clean water resources [2-5]. The design of industrial wastewater treatment is challenging due to various factors that are related to the characteristics of industrial streams, such as high chemical oxygen demand (COD) load, different $\mathrm{pH}$ values depending on the wastewater origin and salinity levels [6-7]. Anaerobic treatment has been implemented for various industrial influents (e.g. aqueous extractions of winery wastes, biodiesel industry wastewater, soluble fraction of food industry wastes etc.) by the use of configurations such as the anaerobic membrane bioreactors (AnMBRs), the upflow anaerobic sludge blanket reactors (UASB), the expanded granular sludge bed reactors (EGSB), the anaerobic hybrid $(\mathrm{AH})$ reactor, the inverse fluidized bed reactor (IFBR). Moreover, this process offers the potential to produce biogas, which is afterwards utilized for electricity and energy production [4-5, 7-11, 77-79]. With a view to achieving a sustainable performance, wastewater treatment plants are expected to: (i) produce high-quality effluents satisfying the increasingly strict discharge legislation, (ii) expand their wastewater reuse and energy recovery potential in accordance with the concept of circular economy, (iii) have the capacity for upgrading and retrofitting energy-efficient and cost-effective technologies, (iv) decrease the investment costs and, generally, (v) have a low overall environmental impact [2-3, 9, 12-13]. In terms of industrial wastewater treatment, the implementation of anaerobic technology (e.g. AnMBR, UASB etc.) increases the system's efficiency, so that it can meet the standards for the treated effluent reuse or discharge. Nevertheless, the latter does not guarantee the attainment of the desired low environmental footprint since the total energy requirements are not always outweighed by the biogas production [14-16]. The decision-making upon the most appropriate process/configuration depends on several parameters including the specific origin of each wastewater stream. This is due to the fact that several operational parameters (e.g. addition of chemicals, energy requirements etc.) are selected upon the influent origin; thus, it is important to make the most sustainable choice 
[17-18]. In this study, the emphasis is put on the use of anaerobic configurations for the treatment of industrial wastewater streams. Our goal was firstly to investigate how this is correlated with factors such as COD removal, organic loading rate (OLR), $\mathrm{pH}$, temperature, hydraulic retention time (HRT) etc. and, secondly, how these are optimally combined towards a sustainable performance. Biogas production was also used as performance indicator of the examined anaerobic processes. Moreover, life cycle assessment (LCA) of anaerobic industrial wastewater treatment was presented as a method for holistically evaluating the environmental impact resulting from the application of such technologies. Finally, the analysis considered the contribution of anaerobic wastewater treatment technologies to the concept of circular economy by considering the European Commission Innovation Deal that is based on combining sustainable anaerobic membrane wastewater treatment and water reuse.

\section{Technologies for the Biological Treatment of Industrial Wastewater}

This section is dedicated to technologies for the industrial wastewater treatment and reuse; the emphasis is put on schemes, which stand as an alternative to the CAS systems. The activated sludge process (AS), although widely applied, requires the use of chemicals and involves high capital, operational and maintenance costs [5]. The sequencing batch reactors (SBRs) are used for municipal, as well as, industrial wastewater treatment as a more flexible version of the CAS systems. They operate under a sequence of phases (filling, reaction, settling and decantation) within a single tank, which functions both as an equalization tank and as a clarifier. In terms of industrial wastewater treatment, SBRs can be implemented and produce effluents respecting the discharge limits [19-21]. Jiang et al. [22] applied a SBR at lab scale for the treatment of aniline-rich industry wastewater and observed a COD removal of $95.8 \%$. Similarly, Rajab et al. [81] achieved an average total COD removal of $97 \pm 2 \%$ in a lab-scale integrated anaerobic/aerobic SBR treating poultry slaughterhouse wastewater. COD removal higher than $95 \%$ was obtained by Xiao et al. [82] for the treatment of wastewater generated from silicon solar cell manufacture containing isopropyl alcohol operating a lab-scale achieve SBR. Anaerobic treatment is another process that has been widely used for industrial influents treatment [5]. In this process, anaerobic microorganisms convert organic material into usable energy (in the form of biogas) and an amount of biosolids [23]. It occurs either through attached-growth or suspended-growth processes. The main advantages of attached-growth over suspended-growth configurations include lower energy requirements, absence of sludge bulking problems and bigger resistance to system shocks [24-25]. The main configurations for suspended-growth anaerobic wastewater treatment include: the anaerobic membrane bioreactor (AnMBR), the upflow anaerobic sludge blanket reactor 
(UASB), the expanded granular sludge bed (EGSB), the anaerobic hybrid (AH) reactor, the inverse fluidized bed reactor (IFBR) [26-31].

The AnMBR couples the anaerobic suspended-growth bacteria biological process with membranes for solid-liquid separation, thus allowing biomass immobilization. In some configurations, the membrane is placed on the side stream (external, cross-flow configuration) and a recirculation pump provides the required transmembrane pressure within the membrane module. Thus, the cross-flow velocity constantly interrupts the development of a filtration cake onto the membrane. Alternatively, the membrane is submerged either directly in the AnMBR or in a separate chamber. These two configurations require no recirculation pump which reduces the energy consumption and microorganism stress because of lower shear forces due to the absence of the cross-flow effect. However, the anaerobic conditions are less favorable for filtration and more prone to fouling; the latter restricts the full-scale adoption of the process since significantly lower permeate fluxes can be sustained compared to the aerobic MBRs [7, 32]. Nevertheless, successful full-scale AnMBR implementations for the treatment of industrial wastewater exist. The first full-scale AnMBR was installed in North America for the treatment of food industry wastewater with a design influent COD of 39,000 $\mathrm{mg} \mathrm{L}^{-1}$. The average effluent COD was constantly very low $\left(<210 \mathrm{mg} \mathrm{L}^{-1}\right)$. Furthermore, the operating expenses were gradually reduced because the system was capable of progressively developing higher mixed liquor concentrations; thus, there was less need to dewater and dispose the solids [33]. In smaller scale, Van Zyl et al. [34] found a COD removal of 96.8\% in a lab-scale AnMBR treating coal industrial wastewater (influent COD: $18,000 \mathrm{mg} \mathrm{L}^{-1}$ ) and Zayen et al. [35] COD removal of 90.7\% in a pilotscale AnMBR for landfill wastewater (feed solution COD increasing from 15,000 to 30,000 and, finally, to 41,000 $\left.\mathrm{mg} \mathrm{L}^{-1}\right)$. Successful commercial AnMBR applications have also been developed. For instance, Memthane-type AnMBRs have been engineered to produce high-quality effluent through the implementation of ultrafiltration membranes. This system has been successfully applied for the treatment of various industrial streams of high organic strength. Specifically, Memthane technology enabled 95\% COD removal from the wastewater of one of the largest dairy manufactures in South Africa (Woodlands Dairy; influent COD: 10,000 mg L-1). Furthermore, 99\% COD removal became possible for the Paulaner brewery wastewater (Munich, Germany; influent COD: $8,393 \mathrm{mg} \mathrm{L}^{-1}$ ) by the use of this system [84].

The major drivers for the wider adoption of the AnMBR process include: low energy requirements, energy recovery in the form of methane, capacity for removing high organic loads and low sludge production. On the other hand, the main barriers for the extensive AnMBR application are related to the operational cost for the membrane cleaning and replacement due to fouling which can occur by both organic material as well as inorganic 
precipitations (e.g. calcium, nitrogen, phosphorus, magnesium, struvite). Other disadvantages are the energy required for the gas recirculation, the need for nutrient supplementation, the slow growth of the microorganisms involved and the dissolved methane escape in the treated effluent [14, 16, 26, 36-38, 93-95]. The benefits from biogas recovery can counterbalance the operating cost. One example is the world's largest chocolate factory (Mars factory, Veghel, Netherlands; influent COD: 10,000 $\mathrm{mg} \mathrm{L}^{-1}$ ) where wastewater is treated through a Memthanetype AnMBR that achieves almost complete COD removal (99\%). The system can provide 1,000,000 $\mathrm{m}^{3}$ biogas for home boilers and cover $10 \%$ of the plant's total energy requirements [83-84]. Moreover, the energy requirements of a semi-industrial AnMBR plant treating wastewater with high sulfate concentration $\left(105 \mathrm{mg} \mathrm{SO}_{4}\right.$ $\left.\mathrm{S} \mathrm{L}^{-1}\right)$ were minimized to $0.07 \mathrm{kWh} \mathrm{m}^{-3}$ at ambient temperature $\left(17-33^{\circ} \mathrm{C}\right)$ after the sludge retention time (SRT) optimization [39]. Pretel et al. [39] applied the AnMBR technology for the treatment of high-sulfate influents in warm/hot climates resulting in energy production up to $0.11 \mathrm{kWh} \mathrm{m}^{-3}$. At temperatures higher than $25^{\circ} \mathrm{C}$, labscale AnMBRs have been successfully implemented not only for the treatment of low-strength [14, 87-88] but also for high-strength wastewater [85-86] achieving more than 80\% COD removal. Satisfying AnMBR performance under psychrophilic conditions $\left(<20^{\circ} \mathrm{C}\right)$ with approximately $90 \%$ COD removal has been observed for pilot-scale low-strength wastewater treatment [89-90]; the latter supporting the conclusions of past review papers according to which anaerobic low-strength wastewater treatment can be efficiently performed at low temperatures if long SRTs are applied to ensure adequate solids degradation [91-92]. However, proof of successful operation for high-strength wastewater at temperatures around $25^{\circ} \mathrm{C}$ is required to consider the AnMBR as a significantly cost-effective industrial wastewater treatment technology. Finally, the integration of an AnMBR step within a broader treatment system is frequently observed because it is unsure whether the AnMBR technology per se can always meet the strict discharge limits imposed by the current legislative framework. Thus, the AnMBR wide implementation and market penetration are still hindered. In this frame, sustainable wastewater treatment using innovative AnMBR technology has been chosen as one of the two Innovation Deals of the European Commission. The goal is to overcome legislative obstacles and promote the shift from conventional wastewater treatment plants to resource recovery facilities. Following the concept of circular economy, end users are not regarded as simple buyers but as active contributors to a sustainable wastewater treatment that ensures full use of the wastewater value [96-99].

In the UASB process, the sludge granules grow in a tubular reactor [40]. It is applied for anaerobic treatment of domestic wastewater mainly in warm climates; high temperatures offer the appropriate conditions for anaerobic degradation. The latter along with simple operation, limited land requirements and the ability to 
treat at high rate (i.e. at low HRTs) justify the wide UASB application in developing tropical countries [41-43]. The UASB technology has also been widely used for high-strength wastewater achieving stable operation due to high anaerobic reaction rates combined with limited sensitivity to fluctuating parameters (e.g., acidity, HRT) [100]. For example, Djalma Nunes Ferraz Junior et al. [44] developed a lab-scale UASB for the treatment of wastewater coming from ethanol production achieving a COD removal of 96.1 $1.7 \%$ (influent COD=35,200 mg $\left.\mathrm{L}^{-1}\right)$. High organic matter removal efficiencies (COD removal=94.7\%). were obtained with the application of a lab-scale UASB by Sivakumar and Sekaran [45] treating dairy wastewater (influent COD=3,456 $\mathrm{mg} \mathrm{L}^{-1}$ ). However, there are also disadvantages related to the UASB operation. For instance, external additives (e.g. natural polymer, aluminium chloride, powdered bamboo-charcoal etc.) are likely to be needed to enhance sludge granulation and, subsequently, ensure high biomass retention times during high-strength wastewater treatment [100-102]. Moreover, the different kinetics between hydrolysis and methanogenesis can require changes in the reactor design and operation at two discrete stages [103-104]. More importantly, the UASB effluent often fails to comply with strict discharge standards and demands post-treatment through alternative technologies (e.g. SBRs, membrane bioreactors etc.), to remove nutrients and/or increase COD and total suspended solids removal [105106].

EGSB is a modified UASB version, developed to attain higher upflow velocities and accommodate more variable loading rates under a lower footprint $[46,48]$. The higher upflow velocity increases the granular sludge bed fluidization, which, subsequently, improves the contact between wastewater and sludge [47]. Full-scale EGSB applications with significant COD removal have been noted. Petropoulos et al. [48] treated winery wastewater with a lab-scale EGSB $\left(\mathrm{COD}=1,256 \mathrm{mg} \mathrm{L}^{-1}\right)$ and achieved COD removal $\approx 96 \%$ at $37^{\circ} \mathrm{C}$. Ince et al. [107] observed an average COD removal of $86 \pm 8.2 \%$ during the treatment of maize processing wastewater. In addition, Warmenhoven and Spanjers [108] achieved 82\% COD removal while treating fruit juice packaging factory wastewater. $\mathrm{AH}$ is an efficient process that combines anaerobic filtration with the UASB process, achieving stable and economic operation through high SRT but low HRT [49]. It has been effectively applied for industrial wastewaters, such as wine industry wastewater (e.g. lab-scale study by Wahab et al. [49]: influent COD ranging from 500 to $24,000 \mathrm{mg} \mathrm{L}^{-1}$; COD removal=94\%) and brewery wastewater (e.g. lab-scale study by $\mathrm{Li}$ et al. [50]: influent $\mathrm{COD}=108,900-136,700 \mathrm{mg} \mathrm{L}^{-1}$; COD removal=92\%), as well as for leachate treatment (e.g. full-scale study by Mokhtarani et al. [109]: influent $\mathrm{COD}=81,000 \mathrm{mg} \mathrm{L}^{-1}$; COD removal=91\%) [29, 51]. Fluidized beds have been placed within reactors in order to achieve shorter HRTs than the respective ones in the UASB systems. IFBRs can treat higher wastewater volumes in less space, since they provide an increased specific surface area for 
the biomass; thus, shorter HRTs can be applied. The floatable particles have a lower specific density than the liquid; thus, they are fluidized downwards. The produced biogas flows in the opposite direction than the liquid and this enhances the bed expansion. Thus, the fluidization velocities in this inverse system are lower than in the upflow ones, which leads to lower energy consumption [10, 27, 52]. Under lab-scale IFBR implementation, COD removal efficiency higher than 90\% was observed in the studies by Arnaiz et al. [52] for dairy wastewater (influent $\mathrm{COD}=30,000 \mathrm{mg} \mathrm{L}^{-1}$ ) and Alvarado-Lassman et al. [53] for brewery wastewater (influent COD=2,083 $\mathrm{mg} \mathrm{L}^{-1}$ ).

The wastewater treatment sector can majorly contribute to a quicker swift towards circular economy via the wide implementation of breakthrough technologies (e.g. anaerobic reactors) that minimize energy consumption but ensure resource recovery [61]. Suspended-growth systems for anaerobic treatment (AnMBR, UASB, EGSB, AH, IFBR etc.) have been effectively applied for the treatment of industrial influents resulting in high COD removal and energy recovery. The crucial point is to carefully select the design parameters and ensure their optimal combination so that the energy production through anaerobic treatment outweighs any potential cost related to oversizing and membrane cleaning.

\section{Factors Affecting the Performance of Anaerobic Technologies in Industrial Wastewater Treatment}

This section discusses the main factors that affect the performance of the examined anaerobic technologies for the treatment of high-strength industrial wastewater. Table 1 provides an overview of existing studies on the treatment of industrial streams with the implementation of the technologies discussed in section 2 . The goal is to identify how target parameters (e.g. OLR, pH, temperature, HRT) influence the performance of the system in terms of contaminants removal. 
Table 1 Effect of target parameters on the efficiency of alternative anaerobic systems for the treatment of various industrial streams.

\begin{tabular}{|c|c|c|c|c|c|c|c|c|c|}
\hline Reference & $\begin{array}{l}\text { Scale/ } \\
\text { Configuration }\end{array}$ & $\begin{array}{l}\text { Industrial } \\
\text { Wastewate } \\
\text { r Source }\end{array}$ & $\begin{array}{l}\text { Temp. } \\
\left({ }^{\circ} \mathrm{C}\right)\end{array}$ & pH & $\begin{array}{l}\text { HRT or Cycle } \\
\text { duration }\end{array}$ & $\begin{array}{l}\text { OLR } \\
\left(\mathrm{kg} \mathrm{COD} \mathrm{m}^{-3} \mathrm{~d}^{-}\right. \\
\text {1) }\end{array}$ & $\begin{array}{l}\text { Influent COD } \\
\left(\mathrm{mg} \mathrm{L}^{-1}\right)\end{array}$ & $\begin{array}{l}\text { COD } \\
\text { Removal }\end{array}$ & $\begin{array}{l}\text { Biogas production or other } \\
\text { observation }\end{array}$ \\
\hline$[30]$ & $\begin{array}{l}\text { Lab-scale } \\
\text { External- } \\
\text { submerged } \\
\text { AnMBR }\end{array}$ & $\begin{array}{l}\text { Bamboo } \\
\text { industry }\end{array}$ & $28-30$ & $7.4-8$ & 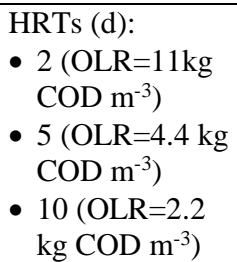 & $\begin{array}{ll}- & 11 \\
& (\mathrm{HRT}=2 \mathrm{~d}) \\
- & 4.4 \\
& (\mathrm{HRT}=5 \mathrm{~d}) \\
- & 2.2 \\
& (\mathrm{HRT}=10 \mathrm{~d})\end{array}$ & 22,000 & $\begin{array}{l}\text { - HRT from } 5 \mathrm{~d} \\
\text { to } 10 \mathrm{~d} \text { : from } \\
91 \% \text { to } 93 \% \\
\text { - HRT from } 10 \mathrm{~d} \\
\text { to } 2 \mathrm{~d} \text { : from } \\
93 \% \text { to } 80 \%\end{array}$ & $\begin{array}{l}\text { - HRT } \geq 5 \text { d: membrane fouling } \\
\text { effectively controlled }\end{array}$ \\
\hline [55] & $\begin{array}{l}\text { Lab-scale } \\
\text { External- } \\
\text { Crossflow UF } \\
\text { AnMBR }\end{array}$ & Distillery & $53-55$ & $7.5-8.5$ & $\mathrm{HRT}=15 \mathrm{~d}$ & 2.06 & 22,600 & $97 \%$ & $\begin{array}{l}\text { - Biogas production rate steadily } \\
\text { increased \& stabilized at } \approx 2.8 \mathrm{~L} \\
\mathrm{~d}^{-1} \\
\text { - Methane content of biogas } \approx \\
55 \%\end{array}$ \\
\hline [54] & $\begin{array}{l}\text { Pilot-scale } \\
\text { External- } \\
\text { Crossflow UF } \\
\text { AnMBR }\end{array}$ & Brewery & $36 \pm 1$ & $6.9-7.2$ & $\mathrm{HRT}=2.5-4.2 \mathrm{~d}$ & 28.5 & $\begin{array}{l}80,000- \\
90,000\end{array}$ & $97 \%$ & $\begin{array}{l}\text { Methane content of biogas } \\
\text { decreased from } 80 \% \text { to } 65 \% \\
\text { towards the end of operation } \\
\text { (probably due to microbial } \\
\text { community changes caused by } \\
\text { the high OLR) } \\
\text { - Methane yield: } 0.28 \mathrm{~m}^{3} \mathrm{CH}_{4}(\mathrm{~kg} \\
\text { COD removed) } \\
\end{array}$ \\
\hline [56] & $\begin{array}{l}\text { Lab-scale } \\
\text { UASB (hollow } \\
\text { centered packed } \\
\text { bed) }\end{array}$ & $\begin{array}{l}\text { Palm oil } \\
\text { mill }\end{array}$ & 55 & $6.8-8$ & $\begin{array}{l}\mathrm{HRT}=2 \mathrm{~d} \text { (for the } \\
\text { optimized set of } \\
\text { operating } \\
\text { parameters) }\end{array}$ & $\begin{array}{l}27.65 \text { (for the } \\
\text { optimized set } \\
\text { of operating } \\
\text { parameters) }\end{array}$ & $32,580 \pm 9,500$ & $\begin{array}{l}91.8 \% \text { (for the } \\
\text { optimized set of } \\
\text { operating } \\
\text { parameters) }\end{array}$ & $\begin{array}{l}\text { - Methane content of biogas } \approx \\
60 \% \\
\text { Max COD removal }(=97.5 \%) \text { at } \\
\text { OLR }=6.66 \mathrm{~kg} \text { COD m }{ }^{-3} \mathrm{~d}^{-1} \\
\text { HRT }=5 \mathrm{~d} \& \text { biogas with } 65.6 \% \\
\text { of methane }\end{array}$ \\
\hline [57] & Pilot-scale UASB & $\begin{array}{l}\text { Sugar- } \\
\text { processing }\end{array}$ & 35 & $6-7$ & $\mathrm{HRT}=1 \mathrm{~d}$ & 13.8 & 128,400 & $87 \%-95 \%$ & $\begin{array}{l}\text { Methane content }=68.5 \% \cdot \text { at } \\
\text { OLR }=13.8 \mathrm{~kg} \mathrm{COD} \mathrm{m}^{-3} \mathrm{~d}^{-1}\end{array}$ \\
\hline
\end{tabular}




\begin{tabular}{|c|c|c|c|c|c|c|c|c|c|}
\hline [58] & Lab-scale EGSB & Brewery & $\begin{array}{l}20 \& \\
15\end{array}$ & $6.8-7.2$ & $\mathrm{HRT}=18 \mathrm{~h}$ & $\begin{array}{l}\text { - } 20^{\circ} \mathrm{C}: 9.7 \\
\text { - } 15^{\circ} \mathrm{C}: 5.5\end{array}$ & $\begin{array}{l}\text { - } 20^{\circ} \mathrm{C}: 7,300 \\
\text { - } 15^{\circ} \mathrm{C}: 5,200\end{array}$ & $\begin{array}{l}\text { - } 20^{\circ} \mathrm{C}:>85 \% \\
\text { - } 15^{\circ} \mathrm{C}: 73 \%\end{array}$ & $\begin{array}{l}\text { - From } 20 \text { to } 15^{\circ} \mathrm{C} \text { : proportion of } \\
\text { Methanosaeta (acetate-utilizing } \\
\text { methanogens) decreased from } \\
60 \% \text { to } 49.3 \% \\
\text { - Reactor performance strongly } \\
\text { influenced by temperature } \\
\text { under psychrophilic conditions }\end{array}$ \\
\hline [59] & Pilot-scale EGSB & $\begin{array}{l}\text { Coal } \\
\text { gasification }\end{array}$ & 35 & $7-7.5$ & $\mathrm{HRT}=4 \mathrm{~d}$ & 0.63 & $2,340-2500$ & $65 \%$ & $\begin{array}{l}\text { - Methane production rate }= \\
227.23 \mathrm{~mL} \mathrm{CH}_{4} \mathrm{~L}^{-1} \mathrm{~d}^{-1} \text { at } \\
\text { OLR=0.63 } \mathrm{kg} \mathrm{COD} \mathrm{m}^{-3} \mathrm{~d}^{-1}\end{array}$ \\
\hline [20] & $\begin{array}{l}\text { Lab-scale } \\
\text { Anaerobic SBR }\end{array}$ & $\begin{array}{l}\text { Palm oil } \\
\text { mill }\end{array}$ & $26-30$ & $\begin{array}{l}8.33- \\
9.14\end{array}$ & $\begin{array}{l}\text { Cycle } \\
\text { duration }=22 \mathrm{~h} \\
\text { (fill, react, settle, } \\
\text { decant) } \\
\end{array}$ & $1.8-4.2$ & $13,950-17,050$ & $95.1 \%-95.7 \%$ & $\begin{array}{l}\text { - Anaerobically digested palm oil } \\
\text { mill effluent requiring aerobic } \\
\text { SBR post-treatment to meet } \\
\text { discharge limits }\end{array}$ \\
\hline [29] & $\begin{array}{l}\text { Lab-scale AH \& } \\
\text { SBR }\end{array}$ & Fruit-juice & 26 & 7.5 & $\begin{array}{l}\text {-Single-stage } \\
\text { AH: } \\
\text { HRT=10.2h } \\
\text { - Two AH } \\
\text { reactors: } \\
\text { HRT=20h } \\
\text { - Two-stage AH } \\
\text { followed by } \\
\text { SBR: HRT=31h }\end{array}$ & $\begin{array}{l}\text { - Single-stage } \\
\text { AH: } 11.8 \\
\text { - Two AH } \\
\text { reactors: } 5.9 \\
\text { - Two-stage } \\
\text { AH followed } \\
\text { by SBR: } 5.3\end{array}$ & $4,980 \pm 1,706$ & $\begin{array}{l}\text { Single-stage } \\
\text { AH: } 42 \% \\
\text { - Two AH } \\
\text { reactors: } 67.4 \% \\
\text { - Two-stage AH } \\
\text { followed by } \\
\text { SBR: } 99 \%\end{array}$ & $\begin{array}{l}\text { Integrated system of two-stage } \\
\text { AH reactors followed by SBR } \\
\text { producing effluent appropriate } \\
\text { for reuse in agriculture }\end{array}$ \\
\hline [27] & Lab-scale IFBR & $\begin{array}{l}\text { Pulp and } \\
\text { Paper }\end{array}$ & $36 \pm 1$ & 7.5 & $\begin{array}{l}\text { - Continuous } \\
\text { operation: } \\
\text { HRT=3.5h } \\
\text { Batch } \\
\text { operation: } \\
\text { HRT }=8 \mathrm{~h}\end{array}$ & 20 & $1,000-8,000$ & $\begin{array}{l}\text { - Continuous } \\
\text { operation: } 81 \% \\
\text { - Batch } \\
\text { operation: } 92 \% \\
\text { (with the } \\
\text { progression of } \\
\text { batch cycles) }\end{array}$ & $\begin{array}{l}\text { - Continuous operation: } 0.237 \mathrm{~L} \\
\mathrm{CH}_{4} \text { (g COD) } \\
\text { - Batch operation: } 0.283 \mathrm{~L} \mathrm{CH}_{4}(\mathrm{~g} \\
\mathrm{COD})^{-1} \text { (with the progression of } \\
\text { batch cycles) }\end{array}$ \\
\hline [10] & Lab-scale IFBR & Dairy & 10 & $6.8-7.2$ & $\mathrm{HRT}=2 \mathrm{~d}$ & 0.5 & 1,000 & $69 \% \pm 10 \%$ & $\begin{array}{l}\text { - Methane production: } 0.241 \mathrm{~L} \\
\mathrm{CH}_{4} \mathrm{~d}^{-1} \\
\text { - Poor mixing in the reactor } \\
\text { provoking poor hydrolysis of } \\
\text { the substrate and, thus, low } \\
\text { COD removal }\end{array}$ \\
\hline
\end{tabular}




\subsection{COD removal}

The origin of the industrial wastewater stream plays an important role in the efficiency of the examined anaerobic processes in terms of COD removal and energy recovery [4]. Speece [60] underlined the effectiveness of anaerobic wastewater treatment for industrial wastewaters, noting, however, that the degradability rate to methane can be variable; the latter is observed because the industrial influent composition can be detrimental to the methanogenic activity.

Table 1 summarizes the results of studies dealing with the treatment of different industrial wastewater streams characterized by different COD levels, all higher or equal to 1,000 $\mathrm{mg} \mathrm{L}^{-1}$. The COD concentration varied from $1,000 \mathrm{mg} \mathrm{L}^{-1}$ [10] (dairy wastewater treated in a lab-scale IFBR) to 80,000-90,000 $\mathrm{mg} \mathrm{L}^{-1}$ [54] (brewery wastewater treated in a pilot-scale AnMBR) and 128,400 $\mathrm{mg} \mathrm{L}^{-1}$ [57] (sugar-processing wastewater treated in a pilot-scale UASB). The results of the studies reported in Table 1 revealed that the application of suitable anaerobic processes can lead to high COD removal efficiencies and high methane production. Anderson et al. [54] and Kim et al. [57] observed that COD was removed by $97 \%$ and $87 \%-95 \%$, respectively. On the contrary, COD removal was only $69 \pm 10 \%$ in the case of the significantly lower influent concentration in the study by Bialek et al. [10]; the cause was insufficiently intense mixing inducing low substrate hydrolysis. After ensuring stable physical conditions (heating, mixing etc.), Anderson et al. [54] noted that the increase of the mixed liquor volatile suspended solids ( 8 to $50 \mathrm{~kg} \mathrm{~m}^{-3}$ ) had no negative effect on the COD removal. Nevertheless, the methanogenic bacteria activity was negatively affected leading to the decrease of the biogas methane content from $80 \%$ to $65 \%$. Kim et al. [57] positively correlated the composition of the active bacterial and archaeal communities (84\% of Lactococcus and $80 \%$ of Methanosaeta, respectively) with the methane production and the OLR $\left(4.01 \mathrm{~L} \mathrm{CH}_{4}\right.$ at $\left.13.8 \mathrm{~kg} \mathrm{COD} \mathrm{m}^{-3} \mathrm{~d}^{-1}\right)$. Microbial network analysis enabled monitoring the response of the active UASB microbial community to different OLRs and, thus, optimizing the process operation.

Due to location-specific nutrient removal limitations and effluent quality concerns, more advanced treatment is often required [110]. COD removal (Table 1) was higher than $80 \%$ for most of the examined processes and initial COD loads. The high COD removal reported in Table 1 gives a preliminary indication of the efficiency of anaerobic treatment either per se or in combination with CAS technologies, as well as its potential to serve the circular economy concept via the simultaneous attainment of nutrient recycling and energy recovery [96]. Anaerobic treatment in combination with CAS process was applied at pilot-scale in the study by Wu et al. [68] where a three-stage system of a catalytic-ceramic-filter anaerobic reactor followed by a UASB and, by an AS reactor at the last stage achieved $98 \%$ COD removal while treating monensin production wastewater. Optimized 
operation ensured satisfying methanogenic activity, anaerobic treatment (with or without the use of pre/posttreatment depending on the location-specific desired nutrient removal and effluent quality) can be a sustainable individual/integrated treatment option for industrial effluents characterized by high levels of organic content.

\subsection{OLR}

In this section, the attention is drawn on the effect that the OLR has on the anaerobic scheme performance. In Table 1, lower OLRs coincided with higher COD removal at a given temperature. The latter was demonstrated in the study by Wang et al. [30] (lab-scale AnMBR treating bamboo industrial wastewater: 80\% of COD removal at OLR=11 kg COD m${ }^{-3} \mathrm{~d}^{-1} ; 93 \%$ COD removal at OLR $=2.2 \mathrm{~kg} \mathrm{COD} \mathrm{m}^{-3} \mathrm{~d}^{-1}$ ), as well as in the work by Poh and Chong [56] (lab-scale UASB for the treatment of palm oil mill wastewater: 91.8\% COD removal at OLR=27.65 $\mathrm{kg} \operatorname{COD~m} \mathrm{m}^{-3} \mathrm{~d}^{-1} ; 97.5 \%$ COD removal at OLR=6.66 $\left.\mathrm{kg} \mathrm{COD} \mathrm{m}^{-3} \mathrm{~d}^{-1}\right)$. Although higher OLRs accelerate granulation, they disturb the balance between acidogenic and methanogenic populations causing poor reactor performance $[56,62]$. Thus, it is essential to test different OLRs for a given temperature and apply the optimal one, which will not jeopardize the biomass activity.

\section{$3.3 \mathrm{pH}$}

Anaerobic digestion strongly depends on the $\mathrm{pH}$ [63]. $\mathrm{pH}$ higher than 9 in a system applying an anaerobic process coupled with membranes has been reported to result in less biogas production and poor membrane performance, since anaerobic treatment takes place at a $\mathrm{pH}$ range of 6.5-8.5, with the optimum $\mathrm{pH}$ range being between 7 and 8 [16, 64-66]. The optimal $\mathrm{pH}$ for the methanogenic bacteria is 6.8-7.2 (i.e. around 7); if it drops below 7, the acidogenic bacteria prevail over the methanogens. As a consequence, acid zones are formed inside the reactors and methane production is reduced [67]. Moreover, $\mathrm{pH}$ shocks lead to dispersion of the sludge flocs. Small-sized particles (e.g. colloids) exist in suspended sludge and provoke increased fouling when AnMBRs are implemented [65]. The $\mathrm{pH}$ is maintained around 7 in most of the studies listed in Table 1. However, $\mathrm{pH}$ stabilization requires the addition of chemicals, especially in the case of industrial streams characterized by low $\mathrm{pH}$ [16]. The need for $\mathrm{pH}$ neutralization increases the overall operational cost, as well as the environmental footprint of the applied process. Thus, the use of chemicals for the adjustment of the influent $\mathrm{pH}$ at $\sim 7$ requires optimization to reduce the environmental impact and cost of an anaerobic process.

\subsection{Temperature}


Higher temperatures $\left(30-55^{\circ} \mathrm{C}\right)$ are favorable for methane production, but disadvantageous in terms of energy requirements. However, temperatures higher than $60^{\circ} \mathrm{C}$ are detrimental to biomass. Thus, in the case of industrial wastewater influents which have high temperatures (e.g. $90^{\circ} \mathrm{C}$ ), pre-cooling is needed for mesophilic (33$\left.42^{\circ} \mathrm{C}\right) /$ thermophilic $\left(50-60^{\circ} \mathrm{C}\right)$ anaerobic treatment $[16,23,47]$. Anaerobic treatment under mesophilic conditions has moderate energy requirements of an industrial influent and results in satisfactory biogas production. Most of the studies included in Table 1 apply the anaerobic process in mesophilic environments. The effect of low temperature in the process performance has been investigated in several studies [10, 58]. Bialek et al. [10] applied psychrophilic conditions in a lab-scale IFBR for dairy wastewater treatment in order to investigate the efficiency of anaerobic treatment in northern countries where the yearly average temperature is below $15^{\circ} \mathrm{C}$. At $10^{\circ} \mathrm{C}$, the system presented a low average removal efficiency $(\sim 69 \%)$ and unstable operation with hydrolysis being the ratelimiting step. Biofilm overgrowth resulted in a decrease in the population of hydrogenotrophic methanogens; the latter limited methane production. Xing et al. [58] examined the operation of a lab-scale EGSB at $20^{\circ} \mathrm{C}$ and $15^{\circ} \mathrm{C}$ for the treatment of brewery wastewater. The proportion of Methanosaeta (acetate-utilizing methanogens) decreased from $60 \%$ to $49.3 \%$ when the temperature dropped from $20^{\circ} \mathrm{C}$ to $15^{\circ} \mathrm{C}$, which subsequently resulted in decreased methane production. COD removal was also affected; at $20^{\circ} \mathrm{C}$, COD removal exceeded $85 \%$ (for an influent $\mathrm{COD}$ of $7,300 \mathrm{mg} \mathrm{L}^{-1}$ ), whereas at $15^{\circ} \mathrm{C} \mathrm{COD}$ removal was $73 \%$ for a lower influent COD maintained at $5,200 \mathrm{mg} \mathrm{L}^{-1}$. It was observed that relatively satisfactory COD removal at the lower -temperature became possible only after the reduction of the wastewater COD content. The application of mesophilic conditions in anaerobic treatment is recommended for the process stability; the latter being translated into the following: optimal conditions for the occurrence of anaerobic decomposition, sufficient COD removal and satisfying methane production.

\subsection{HRT}

Long HRTs are usually applied during anaerobic treatment of industrial effluents to ensure that the substrate hydrolysis and the methanogenesis are given enough time to occur [16]. This is in accordance with the study by Wang et al. [30] who observed a decrease of the COD removal from 93\% to $80 \%$ with the decrease of HRT from 10 to 2 days. Tawfik and El-Kamah [29] achieved 99\% COD removal operating a lab-scale integrated system of a two-stage AH reactor followed by a SBR for the treatment of fruit-juice industry wastewater at a HRT of 1.3 days. The authors also examined shorter HRTs in non-integrated systems including single-stage AH operation 
(HRT=10.2 hours; COD removal=42\%), as well as two-stage AH operation (HRT=20 hours; COD removal $=67.4 \%$ ), but none of them enabled the production of a treated effluent appropriate for reuse in agriculture.

Shorter HRTs lead to a shorter contact time between the sludge and the substrate and, consequently, to a poorer system performance; a significant amount of biomass does not settle and substrate is washed out without appropriate treatment [30]. Over the last 30 years, anaerobic treatment has been efficiently applied in the domain of wastewater treatment [112]. Nevertheless, its wide application has been hindered by the difficulty in retaining the slowly growing anaerobic microorganisms when operating at short HRTs and low temperatures [111]. On the other hand, the need to decrease the overall cost and operate in smaller reactor volumes pushes towards the application of shorter HRTs [69]. AnMBR tanks in specific, that are characterized by a high concentration of suspended solids, are likely to face accumulation of soluble microbial components and increased membrane fouling because of a potentially insufficiently low $\operatorname{HRT}[30,37]$. The latter was one of the main drivers in the study by Wang et al. [30] who tested the effect of different HRTs (2, 5 and 10 days) on the membrane fouling in a lab-scale AnMBR treating a bamboo industry stream; a minimum HRT ( $\geq 5$ days) was required for an effective control of membrane fouling. Thus, it is important to identify the optimal HRT for each configuration performing anaerobic industrial wastewater treatment. It should be the one combining adequate substrate degradation and cost optimization of the process in terms of reactor volumes.

\subsection{Biogas production}

One of the major advantages in anaerobic wastewater treatment is the recovery of biogas which usually has the following composition: 60-65\% of methane $\left(\mathrm{CH}_{4}\right), 35-45 \%$ of carbon dioxide $\left(\mathrm{CO}_{2}\right)$ and $0-5 \%$ of nitrogen $\left(\mathrm{N}_{2}\right)$ [16]. Methane can be used in anaerobic digestion to produce energy. Carbon dioxide has multiple potential uses: cooling, acid replacement, calcium carbonate production (later utilized in gypsum or soda ash production), and carbon source for algae growth. Nitrogen ammonia can be stripped out from wastewater and then be utilized together with sulphuric acid to produce ammonium sulphate. Wastewater can constitute a source of energy and valuable nutrients through the shift from conventional to anaerobic wastewater treatment. Hence, anaerobic wastewater treatment plants can function as resource recovery facilities where any potential operating cost is outweighed by the biogas production $[61,96]$.

Biogas with more than $60 \%$ of methane is required before using it for digester heating, electricity generation and fuel production $[16,56]$. Lower methane yields can be explained by the high methane solubility especially in low temperatures, such as $15^{\circ} \mathrm{C}[16,70]$; this justifies the decreased methanogenic activity in the 
study by Xing et al. [58] (lab-scale EGSB treating brewery wastewater). Higher temperatures benefit methane generation [16]. In addition, $\mathrm{pH}$ can act as an inhibitory factor for biogas generation when it is below 6 or above 8.5 with the optimal $\mathrm{pH}$ for methanogens being around $7[16,67]$. The majority of studies in Table 1 apply a pH around 7 in order to eliminate the effect of this parameter in biogas production. Poh and Chong [56] obtained optimum methane production efficiency and purity (biogas with $65.6 \%$ of methane) combined with a COD removal of $97.5 \%$ by applying OLR $=6.66 \mathrm{~kg} \mathrm{COD} \mathrm{m}^{-3} \mathrm{~d}^{-1}, \mathrm{HRT}=5$ days and thermophilic conditions $\left(55^{\circ} \mathrm{C}\right)$ at $\mathrm{pH} \sim 7$. However, the application of higher OLR and lower HRT (OLR=27.65 $\mathrm{kg} \mathrm{COD} \mathrm{m}^{-3} \mathrm{~d}^{-1}$ and HRT=2 days) resulted in satisfactory biogas methane content (57.4\%) and COD removal efficiency $(91.8 \%)$ with smaller reactor volumes. Process optimization should take into consideration technical, cost and environmental indicators, thus allowing the application of a minimal HRT, the achievement of satisfying COD removal and, finally, a biogas production with sufficient methane content.

\section{Environmental assessment}

Life Cycle Assessment (LCA) is applied for the assessment of the environmental impact associated with a whole process/product/service by considering the environmental load of every single stage during the life cycle of the process/product/service under investigation (Baumann and Tillman, 2004; ISO 14040, 2006; Hospido et al., 2012). LCA has been widely applied in wastewater treatment (Larsen et al., 2007; Corominas et al., 2011; Hospido et al., 2012). However, the LCA of anaerobic processes for industrial wastewater treatment is limited to few studies.

The development of a holistic approach for the environmental impact assessment of full-scale anaerobic processes integrating LCA, qualitative indicators and impact categories is required. In the case of anaerobic industrial wastewater treatment, the LCA impact categories can include energy and resource requirements, sources of greenhouse gas (GHG) emissions, toxicological data, technical costs etc. [71-73]. Georgiopoulou et al. [74] conducted LCA to evaluate the potential environmental and economic impact of five different biological wastewater technologies (AS, high-rate and extended aeration, pre-denitrification, aerated lagoon and anaerobic treatment (UASB reactor)) for full-scale dairy wastewater treatment. Amongst all the alternative scenarios, the results showed that anaerobic treatment proved to be the most environmentally friendly process, resulting in less GHG emissions with the added value of biogas production. The latter is significant from a global warming potential perspective, since methane (GHG contained in the biogas) is utilized for energy production instead of being emitted to the atmosphere. The dissolved methane which escapes in the treated effluent is an issue of concern 
since it is then released into the atmosphere. However, dissolved methane losses are much more critical in dilute sewage such as domestic/municipal wastewater rather than industrial wastewater [113]. Foley et al. [75] examined the environmental impact of three industrial wastewater treatment options (i.e. full-scale inventory data for highrate anaerobic treatment with biogas generation, pilot-scale inventory data for microbial fuel cell treatment with direct electricity generation and lab-scale inventory data for microbial electrolysis cell with hydrogen peroxide $\left(\mathrm{H}_{2} \mathrm{O}_{2}\right)$ production) through a LCA. Negative environmental impacts were principally associated with electricity consumption and transportation/disposal of biosolids in all the examined options. Anaerobic treatment demonstrated a more environmentally friendly performance in terms of resource requirements and GHG generation, though. O'Connor et al. [76] assessed and compared the environmental performance of fourteen processes (constructed from six unit processes: dissolved air flotation, clarification, AS, UASB, ultrafiltration and reverse osmosis) for the full-scale treatment of pulp and paper effluent in terms of various impact categories (i.e. GHG emissions, water recovery, freshwater aquatic ecotoxicity, eutrophication discharge impact reduction). LCA indicated that AS pre-treatment in the UASB resulted in reduction of the freshwater aquatic ecotoxicity, eutrophication and GHG emissions impact categories.

The way in which the operating strategy and design affect the environmental performance of anaerobic technology is still relatively unclear [80]. In this section though, it has been indicated that anaerobic reactors can have a positive environmental assessment especially in terms of GHG emissions. In any case, anaerobic wastewater treatment should be designed considering both economic (e.g. construction, operation, maintenance costs, etc.) and environmental aspects (e.g. eutrophication, GHG emissions, marine ecotoxicity, etc.) to achieve a positive environmental performance. Marine and freshwater eutrophication can only be decreased if the anaerobic treatment is coupled with suitable anaerobic/anoxic post-treatment.

\section{Anaerobic wastewater treatment within the concept of circular economy}

Wastewater treatment based on the circular economy principles aims at resource recovery and water reuse, reducing energy requirements and chemical consumption as well as at decreasing the environmental impacts. Anaerobic technology for industrial wastewater treatment has the potential to serve the concept of circular economy and has been included in one of the two Innovation Deals of the European Commission. Its wide application can transform wastewater treatment plants into facilities which allow the recovery of water, energy, nutrients and other chemicals along with the reuse of reclaimed water in various sectors (e.g. agriculture, industry, 
drinking water, etc.). Under such circumstances, the end-users of the anaerobically treated wastewater become actively engaged in the effort to shift from conventional wastewater treatment to resource recovery plants [96]. Based on this novel vision on wastewater treatment, wastewater treatment plants will move further from treatment of sewage and play multiple roles: resource factories, energy producers, used water refineries, water recycle and reuse facilities. For instance, part of the reused and nutrient-rich water can be used for irrigation/fertigation, thus reducing water and fertilizer costs in agriculture. It can also undergo further treatment to reach higher quality water for alternative uses such as aquifer recharge. Moreover, reclaimed water can be utilized in industries to cover the water needs for several purposes such as evaporative cooling, boiler feed, washing and mixing [61]. Following the Innovation Deal proposal, sustainable wastewater treatment combining anaerobic treatment with membrane technology and water reuse is the target. Nevertheless, actions are still needed to achieve this goal; e.g. review the legal barriers which often hinder and restrict and water reuse, promote the collaboration between entities and water management stakeholders, disseminate the results to the potential end-users and society.

\section{Conclusions}

In this mini review, anaerobic wastewater treatment (e.g. AnMBRs, UASB, EGSB, AH, IFBR configurations) was presented as an efficient way to treat industrial wastewater streams and produce treated effluents that can meet location-specific discharge limits. More importantly, the implementation of anaerobic technologies was analysed as a means to transform wastewater treatment plants into water reuse and energy recovery facilities in line with the concept of circular economy.

Parameters such as COD removal, OLR, $\mathrm{pH}$, temperature and HRT were examined to see how they are related to the anaerobic configurations performance and how they can be optimally combined. Biogas production was additionally considered as an indicator of the anaerobic plants contribution to energy recovery and, hence, as a way to compensate for part of the operating costs. Moreover, LCA of anaerobic industrial wastewater treatment was presented as a method to examine potential environmental impacts.

Stable operating conditions, intense mixing and, consequently, sufficient substrate degradation are required to achieve satisfying COD removal. Furthermore, the application of an optimal OLR coupled with a suitable temperate is needed to maintain the balance between acidogenic and methanogenic populations without compromising the reactor performance. Moreover, optimal reactor performance calls for $\mathrm{pH}$ stabilization around 7, operation in a mesophilic environment and application of a minimal HRT to ensure satisfying substrate 
degradation and enhanced biogas production (with sufficient methane content) under economically acceptable reactor volumes. In that case, efficient treatment is achieved together with energy recovery without high operational/maintenance costs and significant negative environmental impacts. Especially in terms of GHG emissions as a LCA impact category, anaerobic technologies for industrial wastewater treatment can be positively assessed provided that the dissolved methane escaping with the treated effluent is limited; methane (GHG) contained in the biogas produced through anaerobic treated is converted to energy instead of being emitted to the atmosphere.

According to the principles of circular economy, wastewater can be regarded as a source of energy and nutrients. Anaerobic technology for industrial wastewater treatment has been integrated in the two Innovation Deals of the European Commission that focus on attaining sustainable wastewater treatment along with water reuse. In this frame, the old paradigm of conventional wastewater treatment plants engineered just to perform nutrient removal is expected to be replaced by advanced anaerobic treatment that allows the recovery of water, energy and nutrients, as well as the reuse of water in different domains (e.g. agriculture, industry, drinking water sector, etc.). Within the circular economy concept, end-users are no longer considered as simple consumers but as active participators in an effort to fully exploit wastewater. However, legal barriers concerning water reuse and market exploitation of recovered products, gaps in the cooperation between entities and water management stakeholders as well as limited dissemination still restrict the wide penetration of the anaerobic technology to the market.

\section{References}

1. Baban, A.: Biodegradability Assessment and Treatability of High Strength Complex Industrial Park Wastewater. Clean Soil Air Wat. 41 (10), 976-983 (2013)

2. Lesjean, B., Huisjes, E.H.: Survey of the European MBR market: trends and perspectives. Desalination 231, 71-81 (2008)

3. Huisjes, E.H., Colombel, K., Lesjean, B.: The European MBR Market: specificities and future trends. MBR-Network Workshop, $31^{\text {st }}$ March - $1^{\text {st }}$ April 2009, Berlin, Germany (2009)

4. Shakerkhatibi, M., Monajemi, P., Jafarzadeh, M. T., Mokhtari, S.A., Farshchian, M.R.: Feasibility Study on EO/EG Wastewater Treatment Using Pilot Scale SBR. Int. J. Environ. Res. Public Health 7 (1), 195204 (2013) 
5. Gude, V.G.: Wastewater treatment in microbial fuel cells-an overview. J. Clean. Prod. 122, 287-307 (2016)

6. Ozgun, H., Dereli, R.K., Ersahin, M.E., Kinaci, C., Spanjers, H., van Lier, J.B.: A review of anaerobic membrane bioreactors for municipal wastewater treatment: Integration options, limitations and expectations. Sep. Purif. Technol. 118, 89-104 (2013)

7. Dvorak, L., Gómez, M., Dolina, J., Cernín, A.: Anaerobic membrane bioreactors-a mini review with emphasis on industrial wastewater treatment: applications, limitations and perspectives. Desalin. Water Treat. 66, 1-15 (2015)

8. Chan, C.H., Lim, P.E.: Evaluation of sequencing batch reactor performance with aerated and unaerated fill periods in treating phenol-containing wastewater. Bioresour. Technol. 98, 1333-1338 (2007)

9. Desloover, J., De Clippeleir, H., Boeck, P., Du Laing, G., Colsen, J., Verstraete, W., Vlaeminck, S.E.: Floc-based sequential partial nitritation and anammox at full scale with contrasting $\mathrm{N}_{2} \mathrm{O}$ emissions. Water Res. 45, 2811-2821 (2011)

10. Bialek, K., Cysneiros, D., O'Flaherty, V.: Hydrolysis, acidification and methanogenesis during lowtemperature anaerobic digestion of dilute dairy wastewater in an inverted fluidised bioreactor. Appl. Microbiol. Biot. 98, 8737-8750 (2014)

11. Jaouad, Y., Villain, M., Ouazzani, N., Mandi, L., Marrot, B.: Biodegradation of olive mill wastewater in a membrane bioreactor: acclimation of the biomass and constraints. Desalin. Water Treat. 57, 8109-8118 (2016)

12. Santos, A., Ma, W., Judd, S.J.: Membrane bioreactors: Two decades of research and implementation. Desalination 273, 148-154 (2011)

13. Krzeminski, P., van der Graaf, J.H.J.M., van Lier, J.B.: Specific energy consumption of membrane bioreactor (MBR) for sewage treatment. Water Sci. Technol. 65 (2), 380-392 (2012)

14. Hu, A.Y., Stuckey, D.C.: Treatment of dilute wastewaters using a novel submerged anaerobic membrane bioreactor. J. Environ. Eng. 132 (2), 190-198 (2006)

15. Gil, J.A., Tua, L., Rueda, A., Montano, B., Rodriguez, M., Prats, D.: Monitoring and analysis of the energy cost of an MBR. Desalination 250, 997-1001 (2010)

16. Lin, H., Peng, W., Zhang, M., Chen, J., Hong, H., Zhang, Y.: A review on anaerobic membrane bioreactors: Applications, membrane fouling and future perspectives. Desalination 314, 169-188 (2013) 
17. Heinke, G.W., Smith, D.W., Finch, G.R.: Guidelines for the planning and design of wastewater lagoon systems in cold climates. Can. J. Civil Eng. 18, 556-567 (1991)

18. Rodriguez, R., Espada, J.J., Pariente, M.I., Melero, J.A., Martinez, F., Molina, R.: Comparative life cycle assessment (LCA) study of heterogeneous and homogenous Fenton processes for the treatment of pharmaceutical wastewater. J. Clean. Prod. 124, $21-29$ (2016)

19. Mahvi, A.H.: Sequencing batch reactor: a promising technology in wastewater treatment. Iran. J. Environ. Health Sci. Eng. 5 (2), 79-90 (2008)

20. Chan, Y.J., Chong, M.F., Law, C.L.: Biological treatment of anaerobically digested palm oil mill effluent (POME) using a Lab-Scale Sequencing Batch Reactor (SBR). J. Environ. Manage. 91, 1738-1746 (2010)

21. Sirianuntapiboon, S., Chairattanawan, K.: Comparison of sequencing batch reactor (SBR) and granular activated carbon-SBR (GAC-SBR) systems on treatment textile wastewater containing basic dye. Desalin. Water Treat. 57 (56) 1-17 (2016)

22. Jiang, Y., Wang, H., Shang, Y., Yang, K.: Simultaneous removal of aniline, nitrogen and phosphorus in aniline-containing wastewater treatment by using sequencing batch reactor. Bioresour. Technol. 207, $422-429(2016)$

23. Dereli, R.K., Ersahin, M.E., Ozgun, H., Ozturk, I., Jeison, D., van der Zee, F., van Lier, J.B.: Potentials of anaerobic membrane bioreactors to overcome treatment limitations induced by industrial wastewaters. Bioresour. Technol. 122, 160-170 (2012)

24. Metcalf \& Eddy: Wastewater Engineering: Treatment and Reuse. Revised by Tchobanoglous, G., Burton, F. L., Stensel, H. D., McGraw-Hill Education, New York, US (2003)

25. Dabi, N.: Comparison of Suspended Growth and Attached Growth Wastewater Treatment Process: A Case Study of Wastewater Treatment Plant at MNIT, Jaipur, Rajasthan, India. Euro. J. Adv. Eng. Tech. $2(2), 102-105(2015)$

26. Liao; B.Q., Kraemer, J.T., Bagley, D.M.: Anaerobic Membrane Bioreactors: Applications and Research Directions. Crit. Rev. Env. Sci. Tec. 36 (6), 489-530 (2006)

27. Alvarado-Lassman, A., Sandoval-Ramos, A., Flores-Altamirano, M.G., Vallejo-Cantu, N.A., MendezContreras, J.M.: Strategies for the Startup of Methanogenic Inverse Fluidized-Bed Reactors Using Colonized Particles. Water Environ. Res. 82 (5), 387-391 (2010) 
28. Feng, Y., Lu, B., Jiang, Y., Chen, Y., Shen, S.: Anaerobic degradation of purified terephthalic acid wastewater using a novel, rapid mass-transfer circulating fluidized bed. Water Sci. Technol. 65 (11), 1988-1993 (2012)

29. Tawfik, A., El-Kamah, H.: Treatment of fruit-juice industry wastewater in a two-stage anaerobic hybrid (AH) reactor system followed by a sequencing batch reactor (SBR). Environ. Technol. 33 (4), 429-436 (2012)

30. Wang, W., Yang, Q., Zheng, S., Wu, D.: Anaerobic membrane bioreactor (AnMBR) for bamboo industry wastewater treatment. Bioresour. Technol., 149, 292-300 (2013)

31. Duan, W., Ronen, A., Valle de Leon, J., Dudchenko, A., Yao, S., Corbala-Delgado, J., Yan, A., Matsumoto, M., Jassby, D.: Treating anaerobic sequencing batch reactor effluent with electrically conducting ultrafiltration and nanofiltration membranes for fouling control. J. Membr. Sci., 504, 104$112(2016)$

32. Chang, S.: Anaerobic Membrane Bioreactors (AnMBR) for Wastewater Treatment. Adv. Chem. Eng. Sci. 4, 56-61 (2014)

33. Christian, S., Grant, S., McCarthy, P., Wilson, D., Mills, D.: The first two years of full-scale anaerobic membrane bioreactor (AnMBR) operation treating high-strength industrial wastewater. Water Pract. Tech. 6 (2), 4019-4033 (2011)

34. Van Zyl, P.J., Wentzel, M.C., Ekama G.A., Riedel, K.J.: Design and Start-Up of a High Rate Anaerobic Membrane Bioreactor for the Treatment of a Low pH, High Strength, Dissolved Organic Waste Water. Water Sci. Technol. 57 (2), 291-295 (2008)

35. Zayen, A., Mnif, S., Aloui, F., Fki, F., Loukil, S., Bouaziz, M., Sayadi, S.: Anaerobic Membrane Bioreactor for the Treatment of Leachates from Jebel Chakir Discharge in Tunisia. J. Hazard. Mater. 177 (1-3), 918-923 (2010)

36. Speece R.E.: Anaerobic Biotechnology for Industrial Wastewaters. Archae Press, Nashville, Tennessee, US (1996)

37. Huang, Z., Ong, S. L., Ng, H.Y.: Submerged anaerobic membrane bioreactor for low-strength wastewater treatment: Effect of HRT and SRT on treatment performance and membrane fouling. Water Res. 45 (2), 705-713 (2011)

38. Smith, A.L., Skerlos, S.J., Raskin, L.: Psychrophilic anaerobic membrane bioreactor treatment of domestic wastewater. Water Res. 47 (4), 1655-1665 (2013) 
39. Pretel, R., Robles, A., Ruano, M.V., Seco, A., Ferrera, J.: The operating cost of an anaerobic membrane bioreactor (AnMBR) treating sulphate-rich urban wastewater. Sep. Purif. Technol. 126, $30-38$ (2016)

40. Yasar, A., Tabinda, A.B.: Anaerobic Treatment of Industrial Wastewater by UASB Reactor Integrated with Chemical Oxidation Processes; an Overview. Pol. J. Environ. Stud. 19 (5), 1051-1061 (2010)

41. Lew, B., Tarre, S., Belavski, M., Green, M.: UASB reactor for domestic wastewater treatment at low temperatures: a comparison between a classical UASB and hybrid UASB-filter reactor. Water Sci. Technol. 49, 295-301 (2004)

42. Sanchez, A., Buntner, D., Garrido, J.M.: Impact of methanogenic pre-treatment on the performance of an aerobic MBR system. Water Res. 47, 1229-1236 (2013)

43. Dias, D.F.C., Possmoser-Nascimento, T.E., Rodrigues, V.A.J., von Sperling, M.: Overall performance evaluation of shallow maturation ponds in series treating UASB reactor effluent: Ten years of intensive monitoring of asystem in Brazil. Ecol. Eng. 71, 206-214 (2014)

44. Djalma Nunes Ferraz Júnior, A., Koyama, M.H., de Araújo Júnior, M.M., Zaiat, M.: Thermophilic anaerobic digestion of raw sugarcane vinasse, Renew. Energ., 89, 245-252 (2016)

45. Sivakumar, R., Sekaran V.: Comparative Study of Performance Evaluation of UASB Reactor for Treating Synthetic Dairy Effluent at Psychrophilic and Mesophilic Temperatures. Nat. Env. Poll. Tech. 14 (3), 679-684 (2015)

46. Kato, M.T., Field, J.A., Kleerebezem, R., Lettinga, G.: Treatment of low strength soluble wastewater in UASB reactors. J. Ferment. Bioeng. 77 (6), 679-686 (1994)

47. Rajeshwari, K.V., Balakrishnan, M., Kansal, A., Lata, K., Kishore, V.V.N.: State-of-the-art of anaerobic digestion technology for industrial wastewater treatment. Renew. Sust. Energ. Rev. 4, 135-156 (2000)

48. Petropoulos, E., Cuff, G., Huete, E., Garcia, G., Wade, M., Spera, D., Aloisio, L., Rochard, J., Torres, A., Weichgrebe, D.: Investigating the feasibility and the limits of high rate anaerobic winery wastewater treatment using a hybrid-EGSB bio-reactor. Process Saf. Environ. 102, 107-118 (2016)

49. Wahab, M.A., Habouzit, F., Bernet, N., Steyer, J.P., Jedidi, N., Escudie, R.: Sequential operation of a hybrid anaerobic reactor using a lignocellulosic biomass as biofilm support. Bioresour. Technol. 172, $150-155(2014)$

50. Li, H.T., Li, Y.F.: Performance of a hybrid anaerobic baffled reactor (HABR) treating brewery wastewater', 2010 International Conference on Mechanic Automation and Control Engineering MACE 2010, $26^{\text {th }}-28^{\text {th }}$ June 2010, Wuhan, China (2010) 
51. Wu, M., Wilson, F., Tay, J.H.: Influence of media-packing ratio on performance of anaerobic hybrid reactors. Bioresour. Technol. 71, 151-157 (2000)

52. Arnaiz, C., Buffiere, P., Elmaleh, S., Lebrato, J., Moletta, R.: Anaerobic digestion of dairy wastewater by inverse fluidization: the inverse fluidized bed and the inverse turbulent bed reactors. Environ. Technol. 24 (11), 1431-1443 (2003)

53. Alvarado-Lassman, A., Rustrian, E., Garcia-Alvarado, M.A., Rodriguez-Jimenez, G.C., Houbron, E.: Brewery wastewater treatment using anaerobic inverse fluidized bed reactors. Bioresour. Technol. 99, 3009-3015 (2008)

54. Anderson, G.K., Kasapgil, B., Ince, O.: Microbial Kinetics of a Membrane Anaerobic Reactor System. Environ. Technol. 17, 449-464 (1996)

55. Choo, K.H., Lee, C.H.: Membrane Fouling Mechanisms in the Membrane-Coupled Anaerobic Bioreactor. Water Res. 30 (8), 1771-1780 (1996)

56. Poh, P.E., Chong, M.F.: Upflow anaerobic sludge blanket-hollow centred packed bed (UASB-HCPB) reactor for thermophilic palm oil mill effluent (POME) treatment. Biomass Bioenerg. 67, 231-242 (2014)

57. Kim, T.G., Yun, J., Cho, K.S.: The close relation between Lactococcus and Methanosaeta is a keystone for stable methane production from molasses wastewater in a UASB reactor. Appl. Microbiol. Biotechnol. 99, 8271-8283 (2015)

58. Xing, W., Zuo, J-e., Dai, N., Cheng, J., Li, J.: Reactor performance and microbial community of an EGSB reactor operated at 20 and $15^{\circ} \mathrm{C}$. J. Appl. Microbiol. 107, 848-857 (2009)

59. Li, C., Tabassum, S., Zhang, Z.: An advanced anaerobic expanded granular sludge bed (AnaEG) for the treatment of coal gasification wastewater. RSC. 4, 57580-57586 (2014)

60. Speece, R.E.: Anaerobic biotechnology for industrial wastewater treatment. Environ. Sci. Technol. 17 (9), 416-427 (1983)

61. Water Utility Pathways in a Circular Economy: Charting a Course for Sustainability. Available at: http://www.iwa-network.org/water-utility-pathways-circular-economy-charting-course-sustainability/. Accessed: 24 ${ }^{\text {th }}$ May 2017.

62. Zhou, W., Imai, T., Ukita, M., Li, F., Yuasa, A.: Effect of loading rate on the granulation process and granular activity in a bench scale UASB reactor. Bioresour. Technol. 98, 1386-1392 (2007) 
63. Saleh, M.M.A., Mahmood, U.F.: Anaerobic Digestion Technology for Industrial Wastewater Treatment. $8^{\text {th }}$ International Water Technology Conference, IWTC8 2004, 26 $6^{\text {th }}-28^{\text {th }}$ March 2004, Alexandria, Egypt (2004)

64. Weiland, P.: Biogas production: current state and perspectives. Appl. Microbiol. Biotechnol. 85, 849$860(2010)$

65. Gao, W.J.J., Lin, H.J., Leung, K.T., Liao, B.Q.: Influence of elevated pH shocks on the performance of a submerged anaerobic membrane bioreactor. Process Biochem. 45, 1279-1287 (2010)

66. Skouteris, G., Hermosilla, D., Lopez, P., Negro, C., Blanco, A.: Anaerobic membrane bioreactors for wastewater treatment: A review. Chem. Eng. J. 198-199, 138-148 (2012)

67. Osman, R.M.: Anaerobic Fermentation of Industrial Wastewater (Review Article). OJCES, 1 (1), 50-78 (2014)

68. Wu, S., Qi, Y., Fan, C., Dai, B., Huang, J., Zhou, W., He, S., Gao, L.: Improvement of anaerobic biological treatment effect by catalytic micro-electrolysis for monensin production wastewater. Chem. Eng. J. 296, 260-267 (2016)

69. Stuckey, D.C.: Recent developments in anaerobic membrane reactors. Bioresour. Technol. 122, 137-148 (2012)

70. Brown, N.: Methane dissolved in wastewater exiting UASB reactors: concentration measurement and methods for neutralization. Department of Energy Technology, Royal Institute of Technology (KTH), Stockholm, Sweden (2006)

71. Hospido, A., Sanchez, I., Rodriguez-Garcia, G., Iglesias, A., Buntner, D., Reif, R., Moreira, M.T., Feijoo, G.: Are all membrane reactors equal from an environmental point of view? Desalination 285, 263-270 (2012)

72. Hoibye, L., Clauson-Kaas, J., Wenzel, H., Larsen, H.F., Jacobsen, B.N., Dalgaard, O.: Sustainability assessment of advanced wastewater treatment technologies. Water Sci. Technol. 58 (5), 963-968 (2008)

73. Lazarova, V., Martin, S., Bonroy, J., Dauthuille, P.: Main Strategies for Improvement of Energy Efficiency of Membrane Bioreactors. IWA Regular Conference on Membrane Technology and Water Reuse, MTWR, $18^{\text {th }}-22^{\text {th }}$ October 2010, Istanbul, Turkey, 1078-1080 (2011)

74. Georgiopoulou, M., Abeliotis, K., Kornaros, M., Lyberatos, G.: Selection of the best available technology for industrial wastewater treatment based on environmental evaluation of alternative treatment technologies: the case of milk industry. Fresen. Environ. Bull. 17 (1), 1-12 (2008) 
75. Foley, J., Rozendal, R.A., Hertle, C.K., Lant, P.A., Rabaey, K.: Life Cycle Assessment of High-Rate Anaerobic Treatment, Microbial Fuel Cells, and Microbial Electrolysis Cells. Environ. Sci. Technol. 44, 3629-3637 (2010)

76. O'Connor, M., Garnier, G., Batchelor, W.: Life cycle assessment comparison of industrial effluent management strategies. J. Clean. Prod. 79, 168-181 (2014)

77. Queiroz, L.M., Nascimento, I.O.C., de Melo, S.A.B.V., Kalid, R.A.: Aerobic, Anaerobic Treatability and Biogas Production Potential of a Wastewater from a Biodiesel Industry. Waste Biomass Valor. 7, 691$702(2016)$

78. Nikolaidou, E. Iossifidou, M., Tataki, V., Eftaxias, A., Aivasidis, A., Diamantis, V.: Energy Recovery and Treatment of Winery Wastes by a Compact Anaerobic Digester. Waste Biomass Valor. 7, 799-805 (2016)

79. Alexandropoulou, M., Antonopoulou, G., Lyberatos, G., Food Industry Waste's Exploitation via Anaerobic Digestion and Fermentative Hydrogen Production in an Up-Flow Column Reactor. Waste Biomass Valor. 7, 711-723 (2016)

80. Smith, A.L., Stadler, L.B., Cao, L., Love, N.G., Raskin, L., Skerlos, S.J.: Navigating Wastewater Energy Recovery 1 Strategies: A Life Cycle Comparison of Anaerobic Membrane Bioreactor and Conventional Treatment Systems with Anaerobic Digestion. Environ. Sci. Technol. 48, 5972-5981 (2014)

81. Rajab, A.R., Salim, M.R., Sohaili, J., Anuar, A.N., Salmiati, Lakkaboyana, S.K.: Performance of integrated anaerobic/aerobic sequencing batch reactor treating poultry slaughterhouse wastewater. Chem. Eng. J. 313, 967-974 (2017)

82. Xiao, Y., Xu, H.Y., Xie, H.M., Yang, Z.H., Zeng, G.M.: Comparison of the treatment for isopropyl alcohol wastewater from silicon solar cell industry using SBR and SBBR. Int. J. Environ. Sci. Technol. 12, 2381-2388 (2015)

83. Dutch Water Sector: Mars commissions methane wastewater treatment plant at world's largest chocolate factory in Veghel, the Netherlands. Posted: $28^{\text {th }}$ October 2014. Available at: http://www.dutchwatersector.com/news-events/news/12127-mars-commissions-memthane-wastewatertreatment-plant-at-world-s-largest.html. Accessed: 27th March 2017.

84. Wave \#5: Insights from Veolia Water Technologies-Creating more value for the Food \& Beverage market. Veolia Publications (2016) 
85. He, Y., Xu, P., Li, C., Zhang, B.: High-concentration food wastewater treatment by an anaerobic membrane bioreactor. Water Res. 39, 4110-4118 (2005)

86. Padmasiri, S.I., Zhang, J., Fitch, M., Norddahl, B., Morgenroth, E., Raskin, L.: Methanogenic population dynamics and performance of an anaerobic membrane bioreactor (AnMBR) treating swine manure under high shear conditions. Water Res. 41, 134-144 (2007)

87. Ho, J., Sung, S.: Anaerobic Membrane Bioreactor Treatment of Synthetic Municipal Wastewater at Ambient Temperature. Water Environ. Res. 81, 922-928 (2009)

88. Kim, J., Kim, K., Ye, H., Lee, E., Shin, C., McCarty, P.L., Bae, J.: Anaerobic fluidized bed membrane bioreactor for wastewater treatment. Environ. Sci. Technol. 45, 576-581 (2011)

89. Martinez-Sosa, D., Helmreich, B., Horn, H.: Anaerobic submerged membrane bioreactor (AnSMBR) treating low-strength wastewater under psychrophilic temperature conditions. Process Biochem. 47, 792$798(2012)$

90. Gouveia, J., Plaza, F., Garralon, G., Fdz-Polanco, F., Peña, M.: Long-term operation of a pilot scale anaerobic membrane bioreactor (AnMBR) for the treatment of municipal wastewater under psychrophilic conditions. Bioresour. Technol. 185, 225-233 (2015)

91. O'Flaherty, V., Collins, G., Mahony, T.: The microbiology and biochemistry of anaerobic bioreactors with relevance to domestic sewage treatment. Rev. Environ. Sci. Biotechnol. 5, 39-55 (2006)

92. Van Haandel, A., Kato, M.T., Cavalcanti, P.F.F., Florencio, L.: Anaerobic reactor design concepts for the treatment of domestic wastewater. Rev. Environ. Sci. Biotechnol. 5, 21-38 (2006)

93. Trzcinski, A.P., Stuckey, D.C.: Inorganic fouling of an anaerobic membrane bioreactor treating leachate from the organic fraction of municipal solid waste (OFMSW) and a polishing aerobic membrane bioreactor. Bioresour. Technol. 204, 17-25 (2016)

94. Ersahin, M.E., Tao, Y., Ozgun, H., Spanjers, H., van Lier, J.B.: Characteristics and role of dynamic membrane layer in anaerobic membrane bioreactors. Biotechnol. Bioeng. 113, 761-771 (2016)

95. Choo, K.H., Kang, I.J., Yoon, S.H., Park, H., Kim, J.H., Adiya, S., Lee, C.H.: Approaches to membrane fouling control in anaerobic membrane bioreactors. Water Sci. Technol. 41, 363-371 (2000)

96. European Commission: Research \& Innovation Deals. Last update: $13^{\text {th }}$ February 2017. Available at: http://ec.europa.eu/research/innovation-deals/index.cfm. Accessed: 6 $6^{\text {th }}$ April 2017.

97. Ersu, C.B., Ong, S.K., Arslankaya, E., Lee, Y.W.: Impact of solids residence time on biological nutrient removal performance of membrane bioreactor. Water Res. 44, 3192-3202 (2010) 
98. Abegglen, C., Ospelt, M., Siegrist, H.: Biological nutrient removal in a small-scale MBR treating household wastewater. Water Res. 42, 338-346 (2008)

99. Bekir Ersu, C., Ong, S.K., Arslankaya, E., Brown, P.: Comparison of recirculation configurations for biological nutrient removal in a membrane bioreactor. Water Res. 42, 1651-1663 (2008)

100. Lim, S.J., Kim, T.H.: Applicability and trends of anaerobic granular sludge treatment processes. Biomass Bioenerg. 60, 189-202 (2014)

101. Yu, H.Q., Fang, H.H.P., Tay, J.H.: Enhanced sludge granulation in upflow anaerobic sludge blanket (UASB) reactors by aluminium chloride. Chemosphere 44, 31-36 (2001)

102. Cao, Y., Zhang, M., Shan, S.: Effect of two-added powdered bamboo-charcoal on sludge granulation of UASB reactor. Trans. Chin. Soc. Agr. Eng., 26, 246-250 (2010)

103. Ince, O.: Performance of a two-phase anaerobic digestion system when treating dairy wastewater. Water Res. 32, 2707-2713 (1998)

104. Shin, H.S., Song, Y.C., Lee, C.Y.: Performance of UASB reactor treating leachate from acidogenic fermenter in the two-phase anaerobic digestion of food waste. Water Res. 35, 3441-3447 (2001)

105. Moawad. A., Mahmoud, U.F., El-Khateeb, M.A., El-Molla, E.: Coupling of sequencing batch reactor and UASB reactor for domestic wastewater treatment. Desalination 242, 325-335 (2009)

106. Qiu, G., Song, Y., Zeng, P., Duan, L., Xiao, S.: Combination of upflow anaerobic sludge blanket (UASB) and membrane bioreactor (MBR) for berberine reduction from wastewater and the effects of berberine on bacterial community dynamics. J. Hazard. Mater. 246-247, 34-43 (2013)

107. Ince, B., Cetecioglu, Z., Celikkol, S., Ince, O.: The microbial diversity, methane production, operational routine of an anaerobic reactor treating maize processing wastewater. Water Pract. Technol. 7 (2), 1-8 (2012)

108. Warmenhoven, J.W., Spanjers, H.: TOC based control of anaerobic reactor treating wastewater from a fruit juice packaging factory. Water Pract. Technol. 6 (2), 1-2 (2011)

109. Mokhtarani, N., Bayatfard, A., Mokhtarani, B.: Full scale performance of compost's leachate treatment by biological anaerobic reactors. Waste Manage. Res. 30 (5), 524-529 (2012)

110. Food and Agriculture Organization of the United Nations: Wastewater treatment and use in agriculture. Available at: http://www.fao.org/docrep/t0551e/t0551e05.htm. Accessed: 29 ${ }^{\text {th }}$ May 2017. 
111. Pretel Jolis, R.: Environmental and economic sustainability of submerged anaerobic membrane bioreactors treating urban wastewater. PhD thesis, Universitat Politècnica de València, Valencia, Spain (2015)

112. Lettinga, G., Rebac, S., Zeeman, G.: Challenge of psychrophilic anaerobic wastewater treatment. Trends Biotechnol. 19 (9), 363-370 (2001)

113.Krzeminski, P., Leverette, L., Malamis, S., Katsou, E.: Membrane bioreactors - A review on recent developments in energy reduction, fouling control, novel configurations, LCA and market prospects. J. Membr. Sci. 527, 207-227 